\title{
SupportingInformation
}

\section{A Deep Reduction and Partial Oxidation Strategy for Fabrication of Mesoporous Si Anode for Lithium Ion Batteries}

Jianwen Liang, Xiaona Li, Zhiguo Hou, Wanqun Zhang, Yongchun Zhu, * and Yitai Qian*

The detail information of the yield calculation: The conversion yield calculation is based on the formula as: $\mathrm{Y}=\mathrm{m}_{\mathrm{E}} / \mathrm{m}_{\mathrm{T}} * 100 \%$. Where $\mathrm{Y}$ is the conversion yield, $\mathrm{m}_{\mathrm{E}}$ is the mass of the experimental resulting silicon production, and $\mathrm{m}_{\mathrm{T}}$ is the mass of the theoretical silicon production. In the revised paper, more several repeated experiments have also been provided. Table $\mathbf{S 1}$ shows the data of four typical repeated experiments of A-Si products and these corresponding conversion yields. As an example, four repeated experiments conversion yields of A-Si is $96.1 \%, 97.3 \%, 91.7 \%$ and $98.3 \%$. Thus, the conversion yield of A-Si is calculated and declared to be higher than $90 \%$.

Table S1. The repeated experiments of A-Si and these corresponding conversion yields.

\begin{tabular}{l|llll}
\hline & $\mathbf{1}$ & $\mathbf{2}$ & $\mathbf{3}$ & $\mathbf{4}$ \\
\hline $\mathbf{m}_{\text {after reduction }} / \mathbf{g}^{\text {a) }}$ & 1.802 & 9.950 & 4.604 & 1.125 \\
$\mathbf{m}_{\text {after oxidation }} / \mathbf{g}^{\text {b) }}$ & 2.218 & 11.77 & 5.868 & 1.480 \\
$\mathbf{m}_{\mathrm{E}} / \mathbf{g}$ & 0.269 & 1.506 & 0.667 & 0.172 \\
$\mathbf{m}_{\mathbf{T}} / \mathbf{g}$ & 0.280 & 1.548 & 0.720 & 0.175 \\
$\mathbf{Y ~} / \%$ & 96.1 & 97.3 & 91.7 & 98.3 \\
\hline
\end{tabular}

a) The mass of the resulting $\mathrm{Mg}_{2} \mathrm{Si}$ intermediate after deep reduction process. ${ }^{\text {b) }}$ The mass of the resulting production after partial oxidation process.

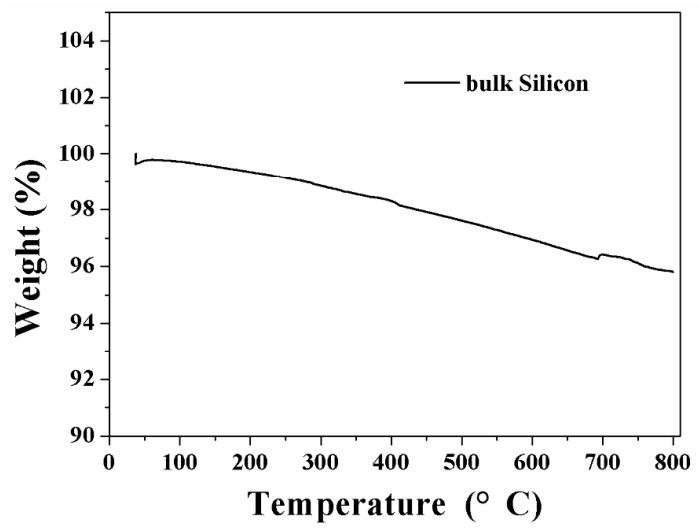

Figure S1. The TGA curves of commercial 200 mesh silicon powder. 

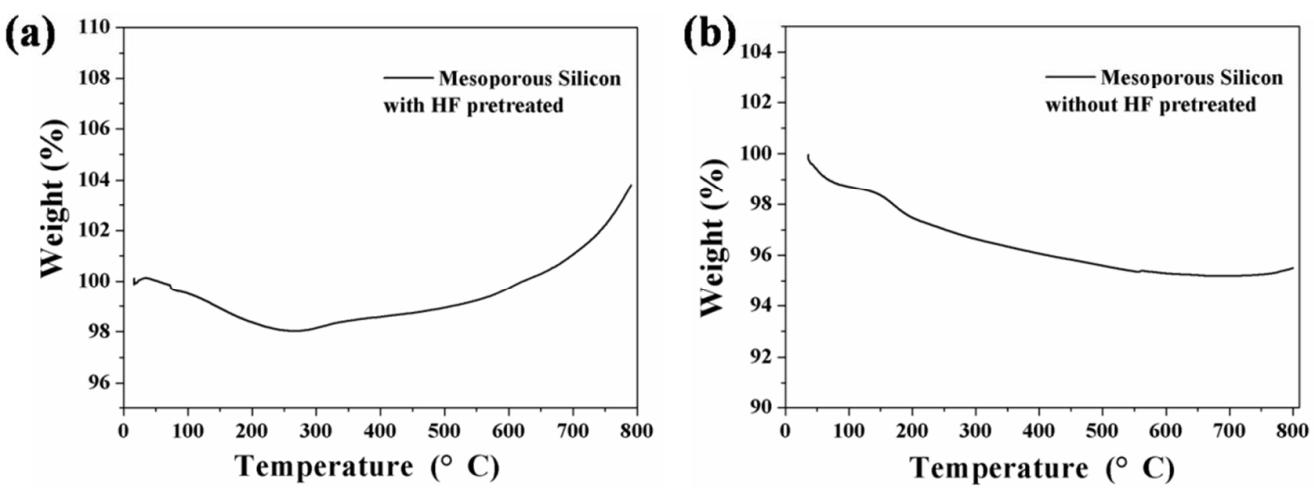

Figure S2. The TGA curves of A-Si materials with HF solution preterated (a) and without HF preterated (b).
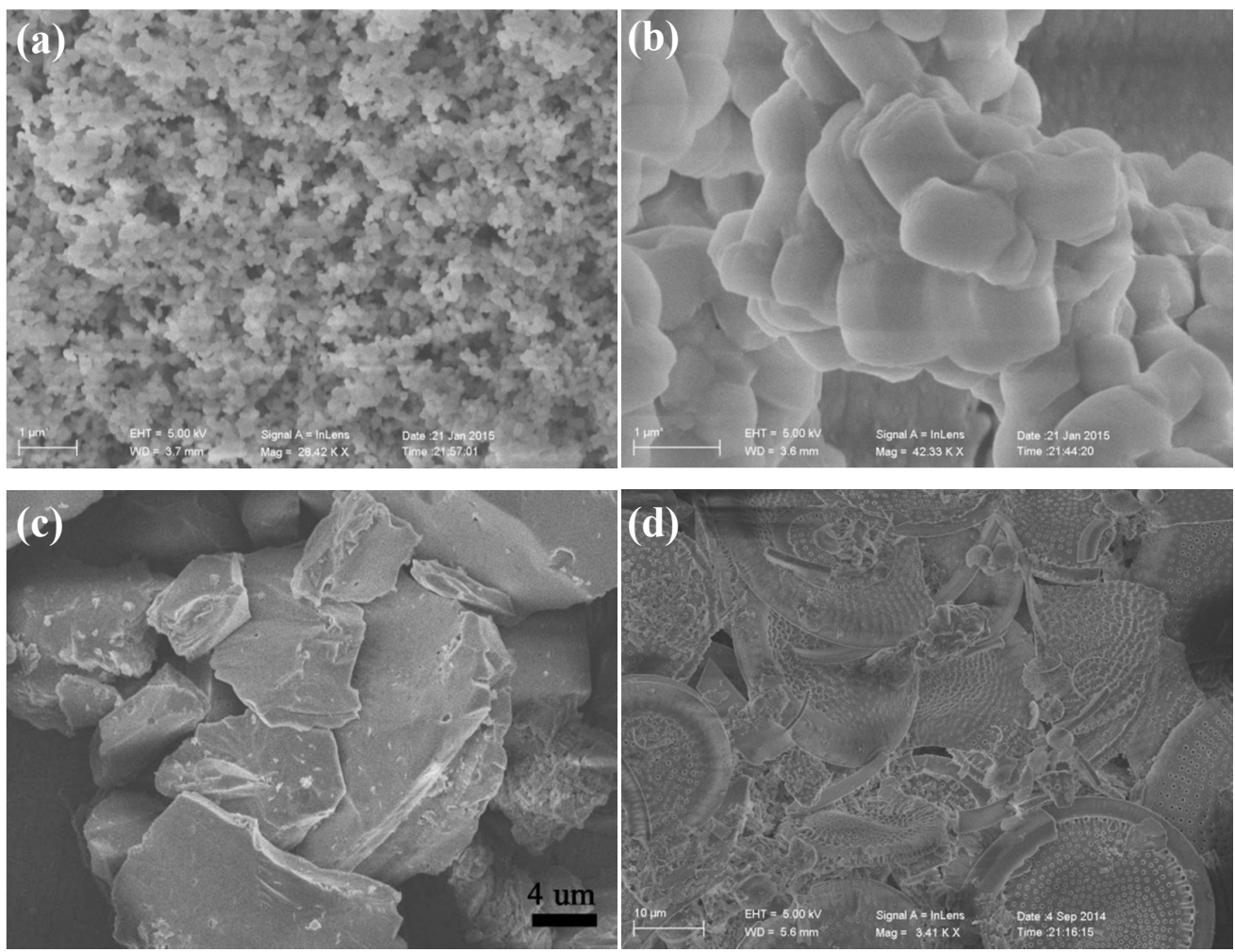

Figure S3. SEM image of the industrial waste silica aerogel (a), silica zeolite previous (b), commercial bulk sand previous (c) and silica adiatom frustule prevous (d). Four different kinds of silica precursor (silica aerogel, silica diatom frustules, commercial sand and silica zeolite) have been chosen based on their specific morphologies, low cost and industrial abundant. Silica aerogel as silica precursor for preparation of A-Si materials is industrial waste coming from ZTT International group. The production of silica aerogel is due to the hydrolysis of $\mathrm{SiCl}_{4}$. Silica diatom frustule is a mineral and composed of the remains of ancient diatoms, which retain the morphology of diatom cell. Commercial sand is come from the Sinopharm Chemical Reagent Co., Ltd (China) with a bulk and solid morphology. Silica zeolite is synthesized by hydrothermal process with the assisting of tri-block copolymer surfactant. Thus, the silica zeolite could form of mesoporous morphology. 


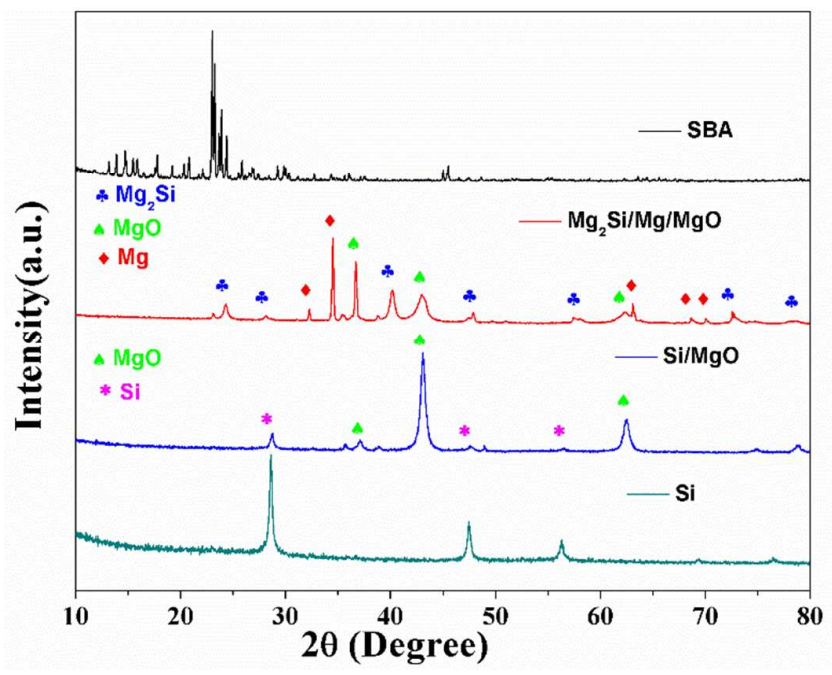

Figure S4. All XRD peaks including intermediated and the resulting production in the synthetic process of S-Si.

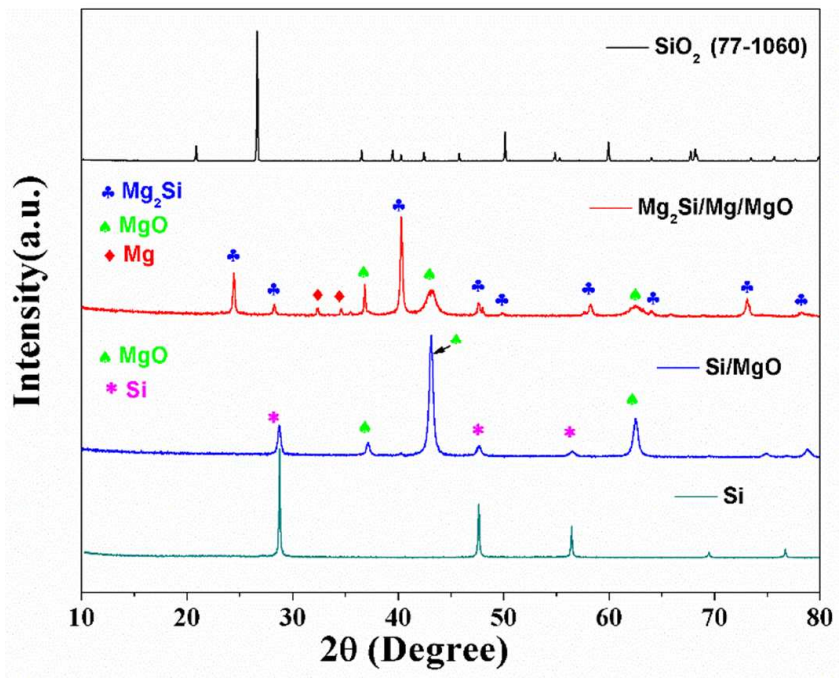

Figure S5. All XRD peaks including intermediated and the resulting production in the synthetic process of C-Si. 


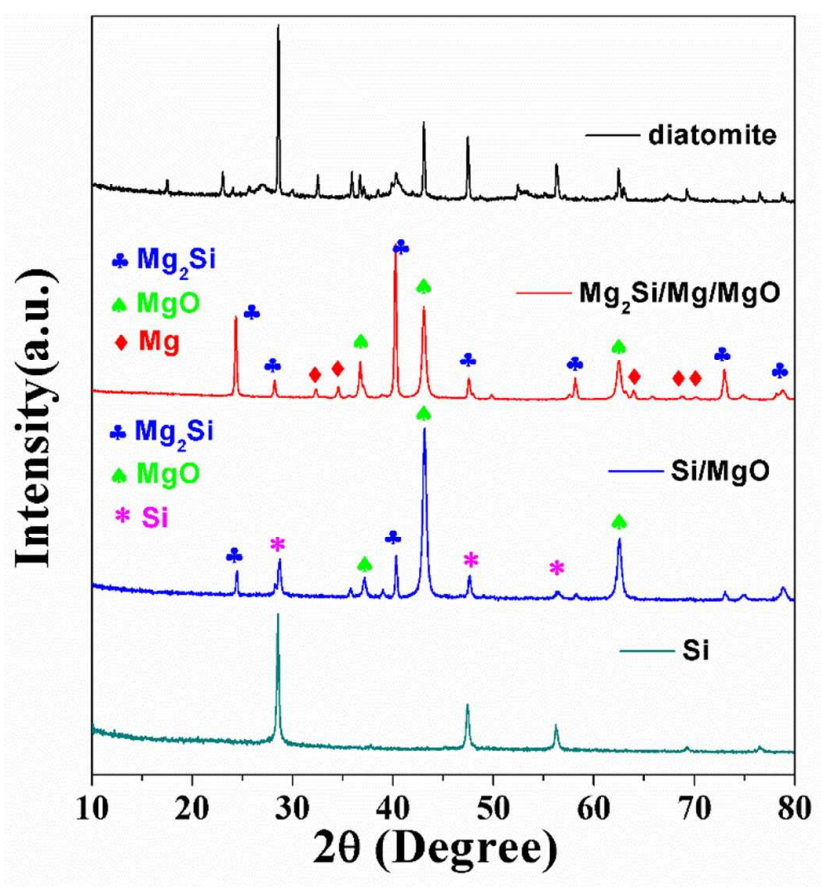

Figure S6. All XRD peaks including intermediated and the resulting production in the synthetic process of D-Si.

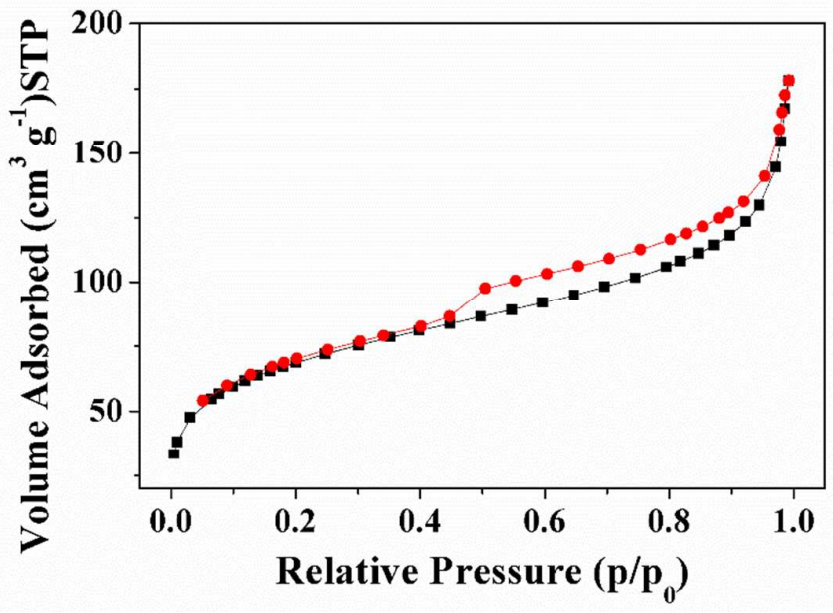

Figure S7. Nitrogen adsorption-desorption curves of the A-Si sample. 


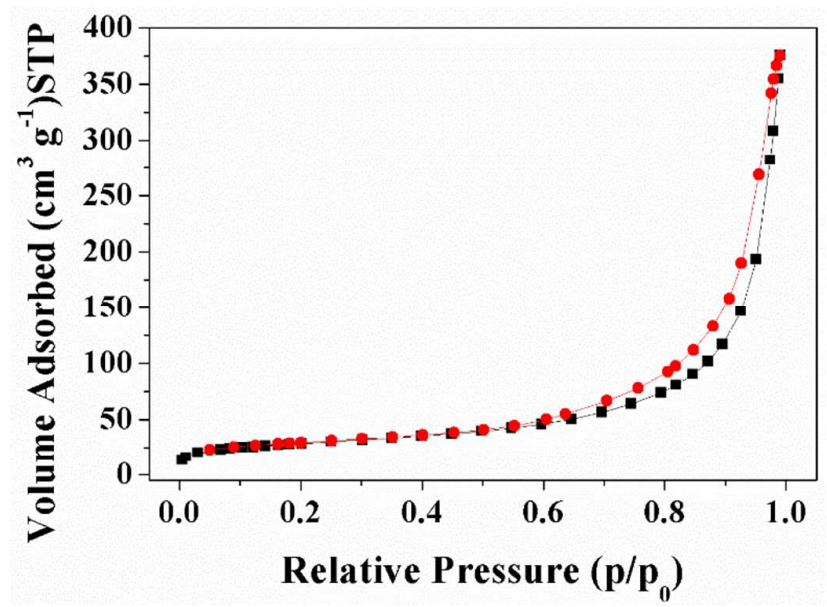

Figure S8. Nitrogen adsorption-desorption curves of the S-Si sample.

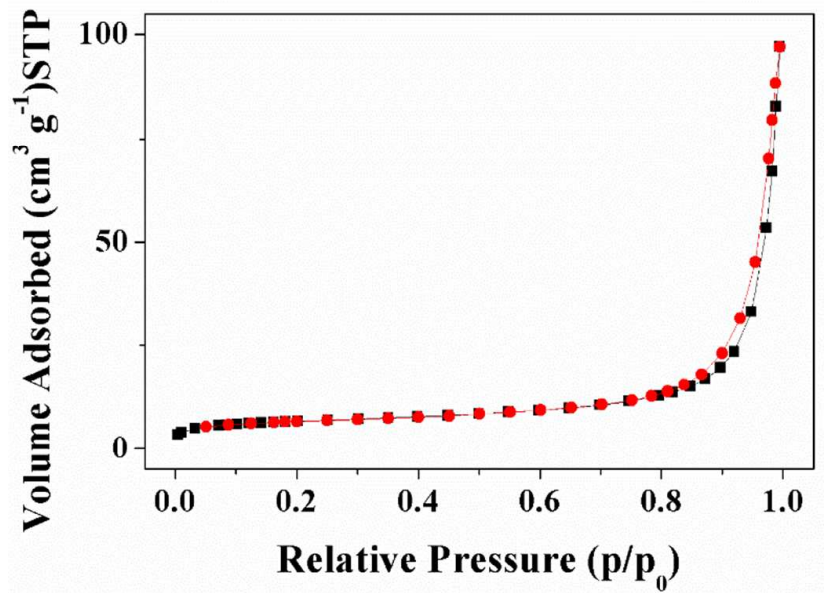

Figure S9. Nitrogen adsorption-desorption curves of the C-Si sample.

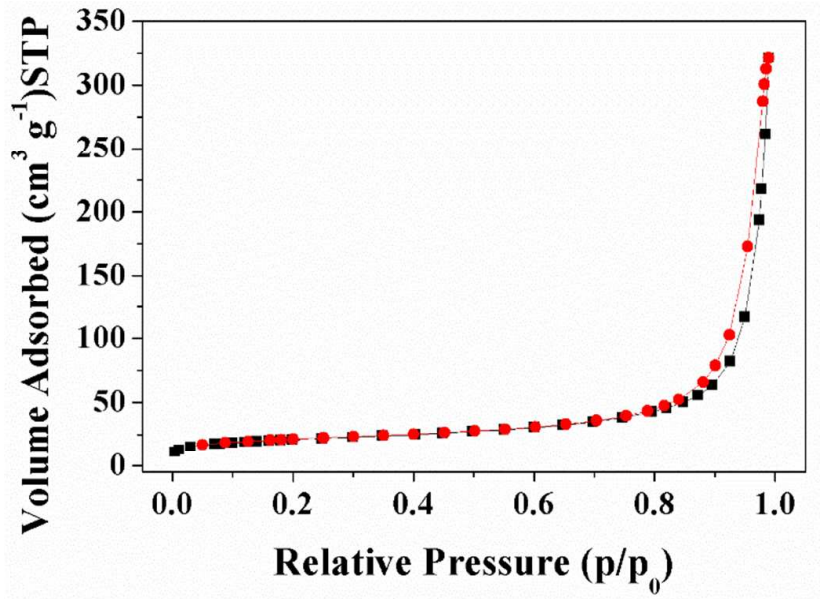

Figure S10. Nitrogen adsorption-desorption curves of the D-Si sample. 


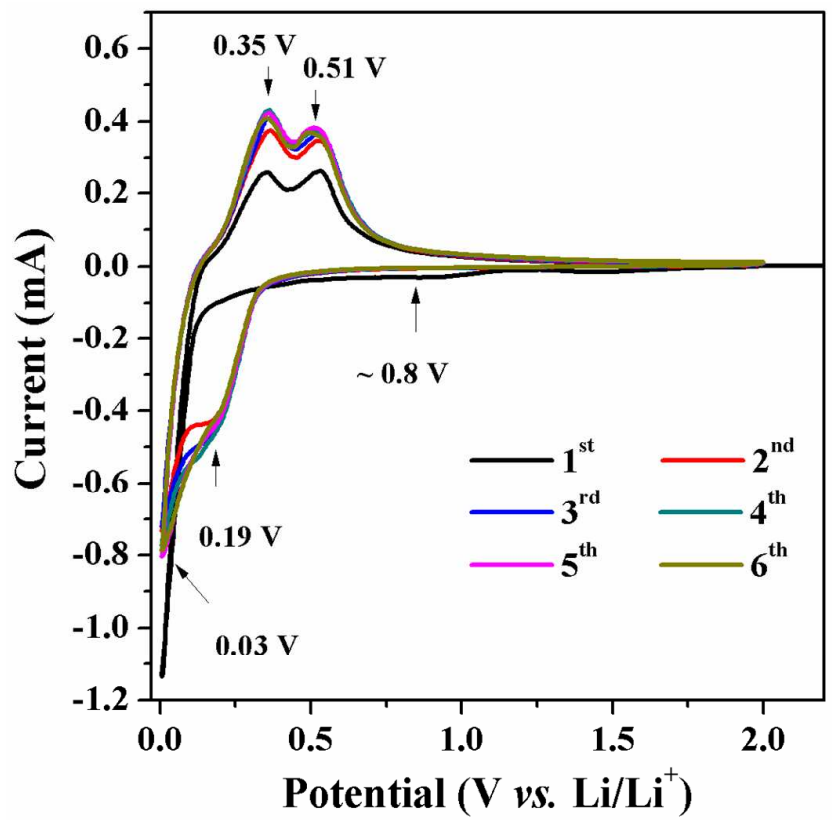

Figure S11. Cyclic voltammetry curves for the first six cycles of A-Si/Li half-cell in the range between 0.01 and $2 \mathrm{~V}\left(v s . \mathrm{Li} / \mathrm{Li}^{+}\right)$at scan rate of $0.1 \mathrm{mV} \mathrm{s}^{-1}$.
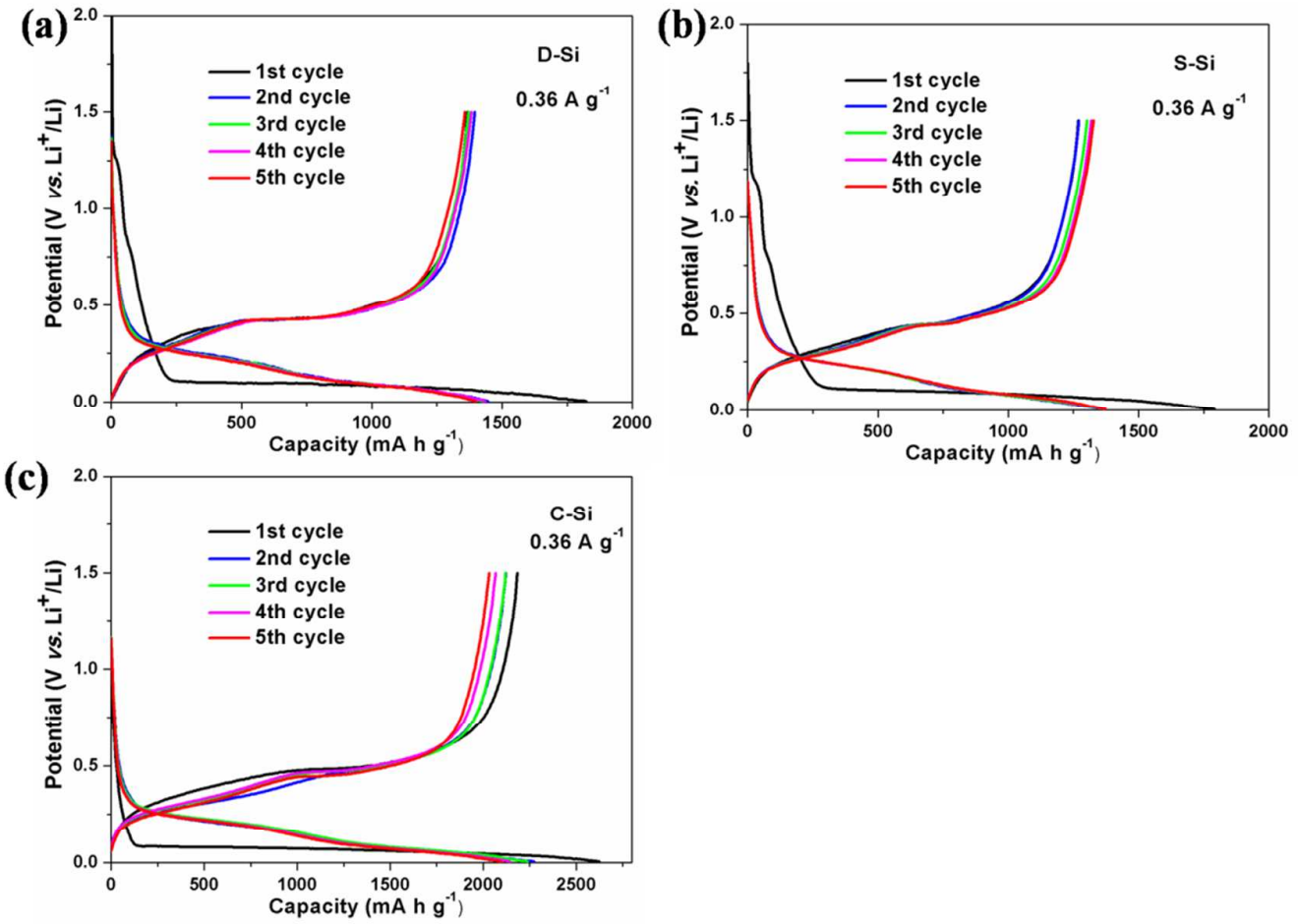

Figure S12. The first five discharge-charge voltage profiles of D-Si anode, S-Si anode and C-Si anode at the current density of $0.36 \mathrm{Ag}^{-1}$. 


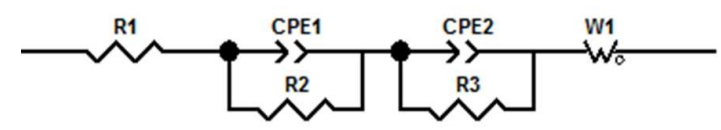

Figure S13. Equivalent circuit used to model the impedance spectra.
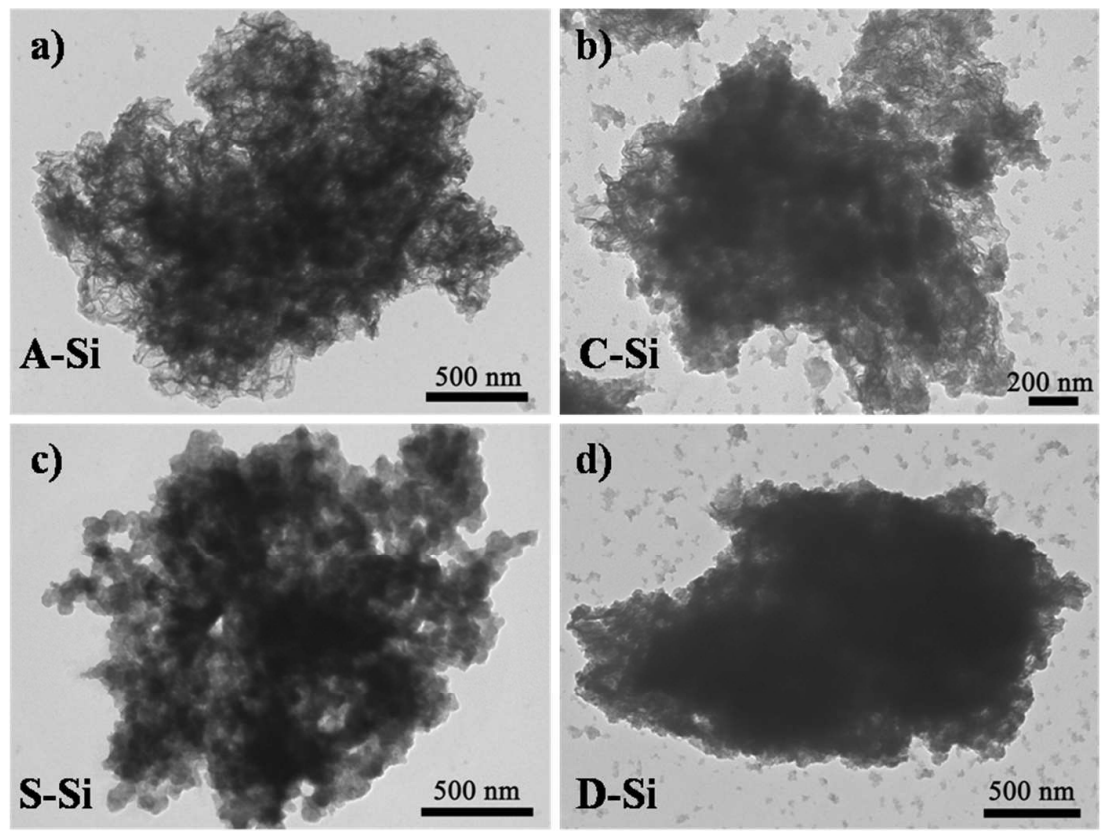

Figure S14. the representative TEM images of the A-Si anode, C-Si anode, S-Si anode and D-Si anode after 100 cycles at $1.8 \mathrm{~A} \mathrm{~g}^{-1}$.
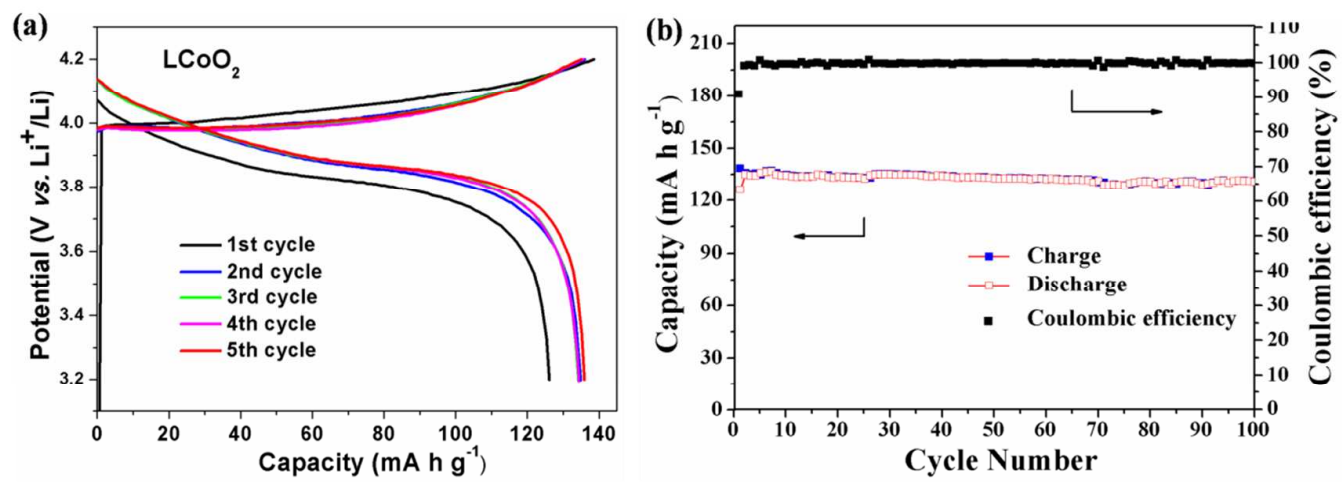

Figure S15. (a) Galvanostatic charge-discharge profiles of the $\mathrm{LiCoO}_{2}$ cathode between 3.2 and $4.2 \mathrm{~V}$ at the current density rate of $1 \mathrm{C}$. (b) Cycling property and coulombic efficiency of the $\mathrm{LiCoO}_{2}$ cathode at $1 \mathrm{C}$. 
Table S2. Comparison of synthetic methods and performance of Si-based LIB anode materials with a long cycle life.

\begin{tabular}{|c|c|c|c|c|c|c|c|c|}
\hline Materials & Method & $\begin{array}{l}\mathrm{HF} \\
\text { involved }\end{array}$ & $\begin{array}{l}\text { Capacity / } \\
\text { mAh g }^{-1}\end{array}$ & $\begin{array}{l}\text { Current } \\
\text { density }\end{array}$ & $\begin{array}{l}\text { Cycle } \\
\text { Number }\end{array}$ & $\begin{array}{l}\text { Capacity } \\
\text { decay rate } \\
\text { (per cycle) }\end{array}$ & $\begin{array}{l}\text { Mass } \\
\text { loading / } \\
\mathrm{mg} \mathrm{cm}^{-2}\end{array}$ & Ref. \\
\hline $\begin{array}{l}\text { Porous doped silicon } \\
\text { nanowires }\end{array}$ & $\begin{array}{l}\text { Etch silicon wafers by } \mathrm{HF} \text { acid } \\
\text { cantaining } \mathrm{Ag}^{+}\end{array}$ & Yes & 2200 & $2 \mathrm{Ag}^{-1}$ & 750 & $0.057 \%$ & --- & S1 \\
\hline Si hollow nanospheres & $\begin{array}{l}\text { CVD deposition of Si on silica template, } \\
\text { follow by HF etching }\end{array}$ & Yes & 1520 & $0.5 \mathrm{C}$ & 700 & $0.08 \%$ & $0.1-0.2$ & S2 \\
\hline Hollow Silicon & $\begin{array}{l}\text { CVD deposition of Si on a corbonates } \\
\text { template followed by } \mathrm{HCl} \text { etching }\end{array}$ & No & 960 & $2.4 \mathrm{~A} \mathrm{~g}^{-1}$ & 500 & $0.059 \%$ & $\sim 1.0$ & S3 \\
\hline $\begin{array}{l}\text { Double walled } \\
\mathrm{Si} / \mathrm{SiO}_{\mathrm{x}} \text { tubes }\end{array}$ & $\begin{array}{l}\text { CVD deposition of Si on a polymer fiber } \\
\text { following by pyrogenic decomposition }\end{array}$ & No & 650 & $24 \mathrm{~A} \mathrm{~g}^{-1}$ & 6000 & $0.0024 \%$ & $0.02-0.1$ & S4 \\
\hline Silicon nanoparticles & $\begin{array}{l}\text { In-situ polymerization of hydrogel in the } \\
\text { electrode fabrication process }\end{array}$ & No & 1750 & $1 \mathrm{Ag}^{-1}$ & 1000 & $0.017 \%$ & $0.3-0.4$ & S5 \\
\hline $\begin{array}{l}\text { Silicon } \\
\text { nanowires/graphene }\end{array}$ & $\begin{array}{l}\text { Si nanowires formation through } \mathrm{HF} / \mathrm{Ag}^{+} \\
\text {solution, follow bycarbon coating }\end{array}$ & Yes & 2050 & $1.3 \mathrm{~A} \mathrm{~g}^{-1}$ & 500 & $0.04 \%$ & 1.5 & S6 \\
\hline $\begin{array}{l}\text { Defect abundant Si } \\
\text { nanorods / C }\end{array}$ & $\begin{array}{l}\text { Etch Al-Si alloys, follow by in-situ } \\
\text { self-polymerization on the silicon } \\
\text { surface and then carbonization }\end{array}$ & No & 700 & $1 \mathrm{Ag}^{-1}$ & 1000 & $0.02 \%$ & 0.9 & S7 \\
\hline $\begin{array}{l}\text { Mesoporous } \mathrm{Si} @ \mathrm{SiO}_{2} \\
\text { (this work) }\end{array}$ & $\begin{array}{l}\text { metallothermic deep reduction of } \\
\text { silicaand then partial air oxidation, } \\
\text { follow by } \mathrm{HCl} \text { etch }\end{array}$ & No & 873 & $1.8 \mathrm{~A} \mathrm{~g}^{-1}$ & 1400 & $0.035 \%$ & $0.7-1.2$ & $\begin{array}{l}\text { This } \\
\text { work }\end{array}$ \\
\hline
\end{tabular}

(S1) Ge, M. Y.; Rong, J. P.; Fang, X.; Zhou, C. W.; Porous Doped Silicon Nanowires for Lithium Ion Battery Anode with Long Cycle Life. Nano Lett., 2012, 12 , 2318. 
(S2) Yao, Yan; McDowell, M. T.; Ryu, I.; Wu, H.; Liu, N.; Hu, L.; Nix, W. D.; Cui, Y. Interconnected Silicon Hollow Nanospheres for Lithium-Ion Battery Anodes with Long Cycle Life. Nano Lett., 2011, 11, 2949-2954.

(S3) Huang, X.; Yang, J.; Mao, S.; Chang, J.; Hallac, P. B.; Fell, C. R.; Metz, B.; Jiang, J.; Hurley, P. T.; Chen, J. Controllable Synthesis of Hollow Si Anode for Long-Cycle-Life Lithium-Ion Batteries. Adv. Mater., 2014, 26, 4326.

(S4) Wu, H.; Chan, G.; Choi, J. W.; Ryu, I.; Yao, Y.; McDowell, M. T.; Lee, S. W.; Jachson, A.; Yang, Y. Stable Cycling of Double-Walled Silicon Nanotube Battery Anodes Through Solid-Electrolyte Interphase Control. Nat. Nanotechnol., 2012, 7, 310-315.

(S5) Wu, H.; Yu, G. H.; Pan, L. J.; Liu, N. A.; McDowell, M. T.; Bao, Z. A.; Cui, Y. Stable Li-Ion Battery Anodes by In-Situ Polymerization of Conducting Hydrogel to Conformally Coat Silicon Nanoparticles. Nat. Commun. 2013, 4, 1943.

(S6) Yang, Y.; Ren, J. G.; Wang, X.; Chui, Y. S.; Wu, Q. H.; Chen, X. F.; Zhang, W. J. Graphene Encapsulated and SiC Reinforced Silicon Nanowires As an Anode Material for Lithium Ion Batteries. Nanoscale 2013, 5, 8689.

(S7) Wang, J.; Meng, X.; Fan, X.; Zhang, W.; Zhang, H.; Wang, C. Scalable Synthesis of Defect Abundant Si Nanorods for High-Performance Li-Ion Battery Anodes. ACS Nano, 2015, 9, 6576. 